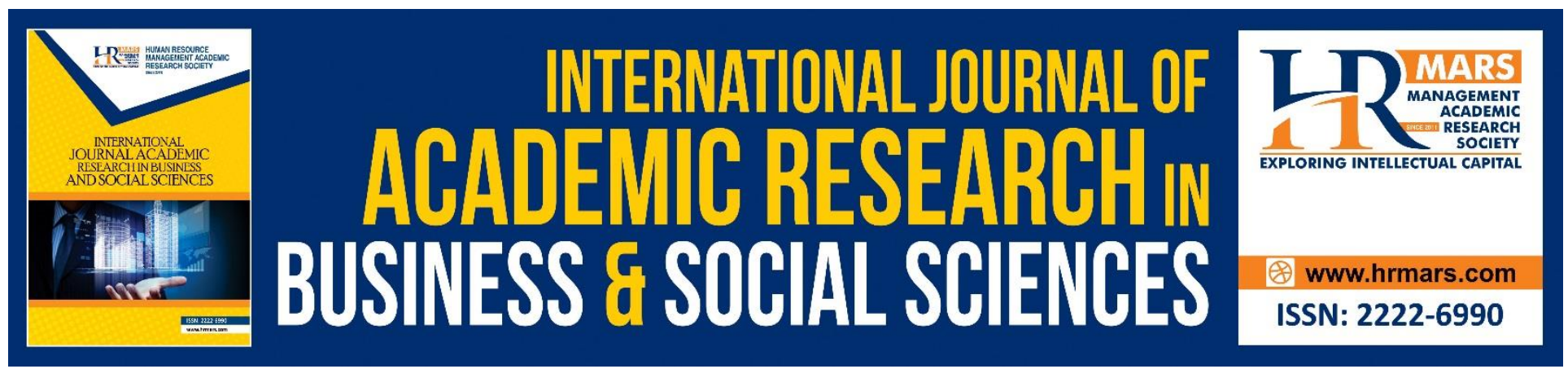

\title{
Application of Decomposed Theory of Planned Behavior on Retail Patronage amongst Women
}

Evelyn Toh Bee Hwa \& Selvan Perumal

To Link this Article: http://dx.doi.org/10.6007/IJARBSS/v8-i11/4951

DOI: $10.6007 /$ IJARBSS/v8-i11/4951

Received: 13 Sept 2018, Revised: 28 Oct 2018, Accepted: 19 Nov 2018

Published Online: 28 Nov 2018

In-Text Citation: (Hwa \& Perumal, 2018)

To Cite this Article: Hwa, E. T. B., \& Perumal, S. (2018). Application of Decomposed Theory of Planned Behavior on Retail Patronage amongst Women. International Journal of Academic Research in Business and Social Sciences, 8(11), 745-757.

Copyright: (C) 2018 The Author(s)

Published by Human Resource Management Academic Research Society (www.hrmars.com)

This article is published under the Creative Commons Attribution (CC BY 4.0) license. Anyone may reproduce, distribute, translate and create derivative works of this article (for both commercial and non-commercial purposes), subject to full attribution to the original publication and authors. The full terms of this license may be seen

at: http://creativecommons.org/licences/by/4.0/legalcode

Vol. 8, No. 11, 2018, Pg. 745 - 757

http://hrmars.com/index.php/pages/detail/IJARBSS

JOURNAL HOMEPAGE

Full Terms \& Conditions of access and use can be found at http://hrmars.com/index.php/pages/detail/publication-ethics 


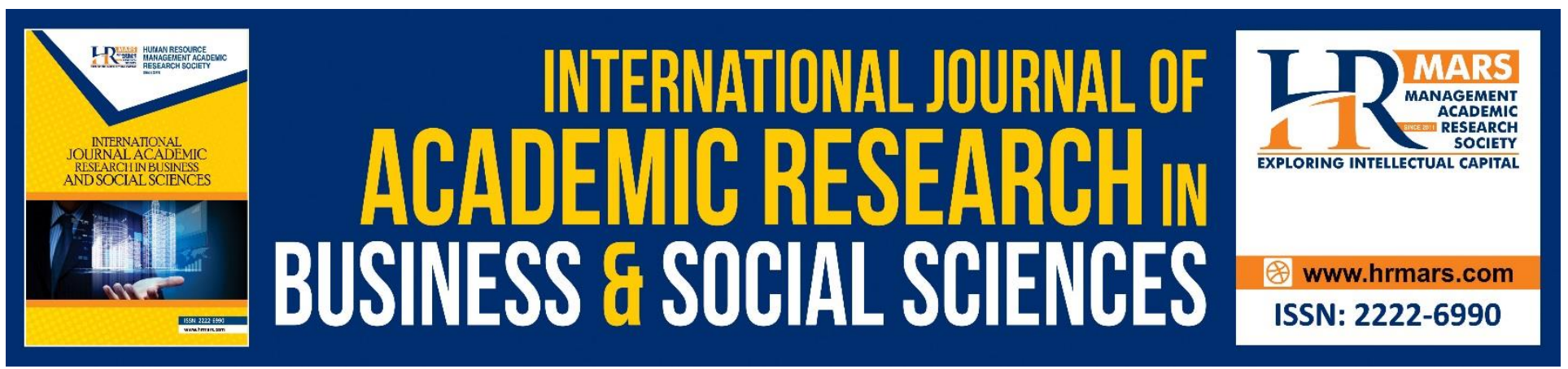

\title{
Application of Decomposed Theory of Planned Behavior on Retail Patronage amongst Women
}

\author{
Evelyn Toh Bee Hwa \\ Sunway University Business School, \\ Sunway University, \\ No. 5, Jalan Universiti, Bandar Sunway, 47500, Selangor D. Ehsan, Malaysia. \\ Selvan Perumal \\ School of Business Management (SBM), \\ Universiti Utara Malaysia, 06010, Sintok, Kedah, Malaysia.
}

\begin{abstract}
The aim of this study is to evaluate the attractiveness of a shopping centre from the type of retail attributes it has. Shopping centres gain the most patronage from women hence this study is about the retail attributes a shopping centre should have in to attract Malaysian women to patronise and shop there. Past research have focused on shopping centres having product related factors (price, product assortment, quality etc.) as factors that would increase patronage intentions amongst women (Toh \& Perumal, 2017) with very little attention placed on the type of retail attributes that may serve to attract women's intention to patronise shopping centres. For this study, a total of 700 questionnaires was distributed and out of this, 423 useable responses were collected and processed. For this study, Smart PLS 3.0 was employed to process for hypothesis testing. The results of this study indicate that the construct of attitude towards a shopping centre mediates the relationship between retail attributes (utilitarian and hedonic) and patronage intention. The use of the decomposed theory of planned behaviour (DTPB) clearly indicate that attitude towards a shopping centre is derived from the retail attributes of a shopping centre.
\end{abstract}

Keywords: Retail Patronage, Attitude, Shopping, DTPB.

\section{INTRODUCTION}

Shopping is classified as the act of an individual having direct contact with the physical architectural features that are incorporated in the constructions of shopping centres / malls (Said, Gambo \& Ismail, 2016). Shopping is seen as a recreational activity that is undertaken by individuals. According to the International Council of Shopping Centres (ICSC), a shopping centre or mall is defined as one or more buildings that form a complex of shops that represent merchandisers that have interconnecting 
walkways that enable shoppers to walk from unit to unit (ICSC, 2013). In order for a shopping centre to be successful, the appropriate market segmentation Attempts to study on the segmentation of shopping centres is prevalent in a study by Ahmed, Ghingold \& Dahari, (2007). This study attempted to distinguish shopping centres indicated that shopping centres provided recreation, amusement and social features and this is separate from the act of purchasing. Apart from this study, there exists little research that was conducted to establish if the retail attributes available in a shopping centre does actually affect women's intention to patronise it. The research model used for this study is based on the decomposed theory of planned behaviour (DTPB) by Taylor \& Tod, (1995).

According to Taylor \& Todd, (1995), the constructs of Attitude (ATT), Subjective Norm (SN) and Perceived Hence, the objectives of this study is to predict women's intention to patronage shopping centres. In order to establish this, this study sought to investigate the factors that would affect customer's shopping attitude and patronage intention. Behavioural Control (PBC) in the theory of planned behaviour (TPB) can be decomposed into multidimensional constructs in order to provide for a better explanation as well as to enhance the predictive power for behaviour intention and behaviour. This study undertakes to study the decomposition of only one construct - attitude. For the construct of attitude, the decomposition looks at the perceived ease of use (PEOU), ease of use (EOU) and compatibility (COMP) which affects the attitude towards a particular shopping centre. As such, the impact of these factors on patronage intention with the mediating effect of attitude towards a shopping centre will be addressed. Figure 1 illustrates the conceptual model of the study.

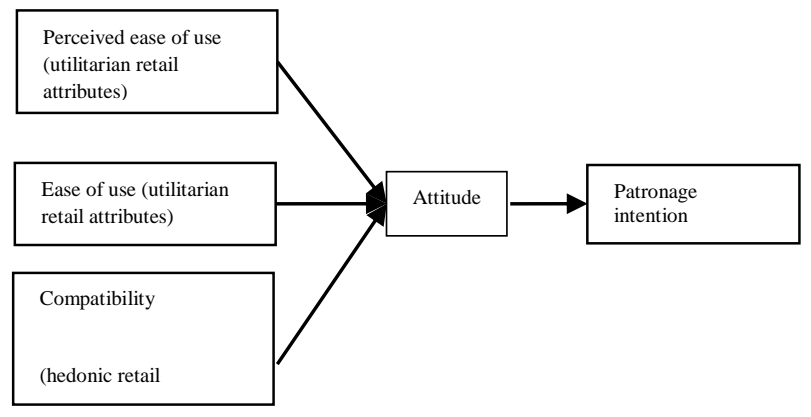

Fig. 1. As such, the impact of these factors on patronage intention with the mediating effect of attitude towards a shopping centre will be addressed. Figure 1 illustrates the conceptual model of the study.

\section{LITERATURE REVIEW \\ RETAIL ATTRIBUTES}

Retail attributes play a very important role in creating retail environments that act to stimulate a consumer's desire to purchase or consume a product or service (Kotler, 1973). According to studies by Zhou \& Wong, (2003) and Tai \& Fung, (1997), retail attributes are considered as the conscious design of a shopping environment to produce specific emotional effects of consumers that enhance their purchase probability. Retail attributes are made up of features such as ambience (i.e. non-visual conditions such as store atmosphere and convenience), design (i.e. visual characteristics such as product quality), and social factors (e.g. human variables such as attitudes of retail employees) that a store or shopping centre has (Turley \& Milliman, 2000). Consumer's perceptions are derived from the retail attributes that are available in the store and this helps them form the overall attitudes 
towards a retail outlet (Darden et al., 1983). Over the years, the retail attributes available in a shopping centre have always played a role in the formation of a retail image. From the management perspective, retail attributes serve as a market positioning tool which can be used to gain competitive advantage amongst each other. As mentioned earlier by Ahmed et. al. (2007), shopping centres can choose to differentiate themselves by segmenting the markets and have adopted different image amongst each other. In marketing sense, the segmentation of a market would enable marketers to better target the consumers. As such, the successful market segmentation in the context of shopping centres would enable retailers to identify a group of customers and match them as precisely as possible to the "retail offering" (Newman and Cullen, 2002). One such example can be derived from the UK fashion sector whereby it exists intense competition and price wars amongst retailers and this has forced retailers to adopt retail positioning that focuses on prices. According to Walters \& Laffy (1996), retail positioning is an integrated strategy that comprises of key management decision areas such as merchandising, store format and design, customer service dimension, and marketing communications. It is through this careful segmentation and retail positioning that retailers can choose a single orientation. For example, Italian shopping centres are positioned as entertainment centres (DeNisco \& Napolitano, 2006). Many other malls / shopping centres have started to concentrate their efforts to create an identity amongst themselves such as a home centre or home deco places. The use of retail attributes as part of the retail positioning strategy has been used previously to study the factors that attract and retain consumers. Consumers that are retained are satisfied customers and they continue to return to the same shopping centre (patronage behaviour) and have a tendency to recommend it to others. Over the years, previous research have centred on the shoppers' choice of one shopping centre over another. The success of a shopping centre is derived from the patronage behaviour of shoppers. A link between retail attributes and patronage behaviour is further explored by a meta-analysis on retail patronage done by Pan \& Zinkhan (2005). In studies that had utilised multi-attribute attitude models which lie in the realm of the general expectancyvalue-approach, the consumer's hedonic and utilitarian evaluation of a shopping centre as well as the value of shopping value is formed by the existence of the retail attribute (Eagly \& Chaiken, 1993). As such this study serves to divide the retail attributes into utilitarian and hedonic retail attributes as a point for evaluation. This is discussed in the subsequent sections.

\section{Utilitarian retail attributes}

Utilitarian retail attributes refer to the retail attributes that are in place in order to satisfy the functional and economic need for shopping. Utilitarian retail attributes consist of price, product assortment, convenience, sales personnel and post transaction satisfaction. These retail attributes are crucial and are in place in order to provide satisfaction to shoppers. This study divides utilitarian retail attributes into two different dimensions - Perceived Ease of Use (PEOU) and Ease of Use (EOU). The term PEOU is derived from its use in the IT setting or adoption of technology whereby it is defined as the prospective user's subjective probability on the specified application system would increase his or her job performance whereas EOU is defined as the degree to which the user expects that the systems is effort free. In this aspect, the user expects the systems to be user-friendly (Davis, 1989). In the retail context, PEOU serves to indicate that utilitarian retail attributes such as price, product 
INTERNATIONAL JOURNAL OF ACADEMIC RESEARCH IN BUSINESS AND SOCIAL SCIENCES

Vol. 8, No. 11, Nov, 2018, E-ISSN: 2222-6990 @ 2018 HRMARS

assortment and sales personnel being in place to satisfy shoppers whereas EOU indicate utilitarian retail attributes such as convenience being in place to satisfy shoppers.

\section{Hedonic retail attributes}

Hedonic retail attributes refer to the retail attributes that serve to stimulate moods and feelings in shoppers. This would consist of the psychological benefits and institutional image that a shopping centre may evoke. Hedonic retail attributes serve to satisfy a shoppers' personal gratification and self-expression associated with the shopping experience. As such, shopping centres serve to provide a pleasant and comfortable atmosphere for shoppers to shop in by generating the ambience to stimulate certain moods amongst shoppers. Previous studies have indicated that shoppers tended to shop in shopping centres that match their self-congruence (Sirgy 1982; 1985), Sirgy, Grewal \& Mangleburg, (2000) \& Sirgy \& Samli (1985). From this, it can be deduced that self-congruence is the degree to which there exists consistency between the ideal self and the actual self. As such the use of the concept of compatibility (COMP) in retail attributes is used to measure if the value or concept matches the shoppers value. The term Compatibility was originally used to refer to the degree in which the innovation fits into the potential adopter's values, previous experiences and current needs (Rogers, 2003).

\section{ATTITUDE}

As mentioned in the previous sections, retail attributes, whether utilitarian or hedonic serve to either attract or distract shoppers. It is from this that shoppers may hold a perception towards these retail attributes. Perception is the process by which an individual is exposed to, attends to, selects, organises and interprets stimuli. This interpretation happens when people draw upon their experiences, memories and expectations which aids in attaching meaning to a stimulus. Perception tends to be short term and should there be any changes in the attributes would result in changes in perception as well. These perceptions are the starting point of attitude formation. Attitude is defined as an individual's disposition, manner, position, feeling, etc. towards a person or object. We can either have a positive or negative disposition or feeling towards a person or an object (Schiffman \& Kanuk, 2010). People also have attitudes towards places they have been or resided in (Jorgensen \& Stedman, 2001). This is no exception for shopping centres. Shoppers form attitudes towards shopping centres based on their perception towards retailers (Morschett, Swoboda \& Foscht, 2005). To provide for a theoretical explanation for this, the theory of planned behaviour (TPB) represents an approach to predict attitude and behaviour (Ajzen \& Fishbein, 1980). This model has been used to describe an individual's attitude toward an object as a function of the individual's expectancy that that object has certain attributes in which he or she places on those attributes. When applied in the context of retail setting, the evaluation of retail attributes would serve to examine the importance of each attribute. The objectives of this study is to establish the evaluative aspects of retail attributes in the attitudes towards shopping centres. As such, the following hypothesis is derived:

$\mathrm{H} 1$ : There is a significant relationship between Perceived Ease of Use (PEOU) and Attitude towards a shopping centre.

$\mathrm{H} 2$ : There is a significant relationship between Ease of Use (EOU) and Attitude towards a shopping centre. 
H3 : There is a significant relationship between Compatibility (COMP) and Attitude towards a shopping centre.

Fishbein \& Ajzen, (1975) have established that attitude towards a behavior is positively related to intention to engage in a behavior. This is further supported by Schiffman \& Kanuk, (2010) whereby a consumers' attitude toward an object or place (retail store) is based on the level of importance that was placed by the consumer towards a store attributes as well as the consumers' perception of the level to which a retail store possesses each attribute. People also form attitudes towards the places they have been to. This was prevalent in the study of attitudes towards location as done by Jorgensen et. al., 2001. This study called Sense of Place (SOP) established that most people form attachments and develop a sense of belongingness to a place and may have already formed an attitude towards it. With regards to shopping centres, the more favourable people's attitude towards a shopping centre, the more likely they are to patronage a shopping centre. As such, the following hypothesis is derived:

H4 : Attitude towards a shopping centre positively influences women's intention to patronage a shopping centre.

This study seeks to establish the use of attitude towards shopping centres as a mediating factor between retail attributes (PEOU, EOU and COMP) and patronage intention. The use of attitude as a mediator is not uncommon as it has been applied in the context of ad effectiveness (Lutz, MacKenzie \& Belch, (1983); Shimp, (1981), brand choice as well as purchase intentions (Spears \& Singh, 2004) as well as post graduate students towards online shopping (Baharun, Mirghasemi, Rahman \& Awang, 2015). As such, the following hypothesis is derived:

$\mathrm{H} 5 \mathrm{a}$ : Attitude towards a shopping centre mediates the relationship between PEOU and patronage intention.

$\mathrm{H} 5 \mathrm{~b}$ : Attitude towards a shopping centre mediates the relationship between EOU and patronage intention.

$\mathrm{H} 5 \mathrm{c}$ : Attitude towards a shopping centre mediates the relationship between COMP and patronage intention.

\section{PATRONAGE INTENTION}

There is a need for retail managers to understand the patronage intention of consumers in order to generate a steady flow of shoppers into the shopping centre. This understanding of patronage behaviour is used to measure the relative appeal of a store or department. From this, the reasons as to why customers do or do not shop in certain retail outlets can be derived. Shopping patronage can be viewed as repeat visits or loyalty as a function of actual buying behaviour (purchase frequency or purchase absence). Satisfied customers would view certain features or attributes of a shopping mall and perceive the quality and assortment of merchandise available there as a measure to make purchases. Therefore, it can be deduced that purchasing frequency is as an indication of mall patronage. Previous research in for retail patronage have looked at different aspects of perceived prices and sales persons' attributes (Darian, Wimana \& Tucci, 2005). Other researchers such as Babin, Chebat \& Michon (2004) have examined the cognitive and affective determinants of retail patronage. 
INTERNATIONAL JOURNAL OF ACADEMIC RESEARCH IN BUSINESS AND SOCIAL SCIENCES

Vol. 8, No. 11, Nov, 2018, E-ISSN: 2222-6990 @ 2018 HRMARS

The concept of retail patronage was further expanded by Teller \& Reutterer (2008) to include marketing mix factors and attractiveness dimensions as a basis to form customer evaluations on a shopping centre which would later determine the patronage behaviour of the customer. Retail patronage can be viewed as a long term loyalty towards a store or establishment which results in store choice and frequency of visit.

\section{METHODOLOGY}

The data that was collected for this study was done via a mall intercept survey. A total of 423 usable questionnaires were collected from 10 different shopping centres located around the Klang Valley. The selected shopping centres differ in size and age. The human population surrounding these shopping centre consisted of suburban middle-class, urban upper class and multicultural. The duration for data collection was three months which coincided with the yearly events for 'Visit Malaysia Year 2016. The questionnaire utilised for this study contained scaled items which were used to measure the variables under investigation: utilitarian retail attributes (PEOU \& EOU), hedonic retail attributes (COMP), attitude towards shopping centres, patronage intention and demographics. In developing the measures for this study, the scales were adopted / adapted from the literature used in this study. The initial measures were further refined pilot tests were conducted in order to enhance face validity. The scale items for all constructs were measured on the Likert scale of 1 to 7 . All the questions are measured on a 7 point Likert scale anchored by "strongly disagree" (1) to "strongly agree" (7). Scale items for Attitude are adapted from Jorgensen \& Stedman (2001) that was originally used in the setting of Sense of Place (SOP) of properties. The scale items for retail attributes (PEOU, EOU and COMP) are adapted from Lee, Atkins, Kim, \& Park (2006). For the measurement of patronage intention, the scale items were adapted from Sharifuddin, Ramalingam, Mohamed \& Rezai (2014).

\section{RESULTS AND FINDINGS}

Before the data is processed in Smart PLS 3.0, rigorous data screening and removal of outliers were first conducted in SPSS version 22. The majority of the respondents were aged between 15 to 24 (79.4\%) followed by 25 to 34 (12.8\%), 35 to 44 (3.5\%), 45 to 54 (1.9\%) and 55 to 64 (2.4\%). Most of the respondents were Single (89.8\%) and did not have children (90.5\%). Most respondents possess a Bachelors' degree $(45.4 \%)$ indicating that the minimum qualification that the respondents had was a degree. Only $61.5 \%$ respondents earned less than RM 5000. In order to ascertain model fit it is important to test the model's reliability and validity. The following sections represent the model's reliability along with the validity of it.

\section{MODEL RELIABILITY AND VALIDITY ASSESSMENT}

In order to examine construct reliabilities, the Composite Reliability is reported. In this study, the composite reliability figures were all well above 0.70 with the range of 0.804 and 0.845 , thus suggesting that the construct reliabilities as being acceptable (Hair, Hult, Ringle \& Sarstedt, 2014). As seen in the table below (Table 1), the loadings are all above zero and this indicates that the factor has a strong effect on the variable. 
INTERNATIONAL JOURNAL OF ACADEMIC RESEARCH IN BUSINESS AND SOCIAL SCIENCES Vol. 8, No. 11, Nov, 2018, E-ISSN: 2222-6990 @ 2018 HRMARS

\begin{tabular}{|c|c|c|}
\hline & $\begin{array}{l}\text { Original } \\
\text { Sample } \\
\text { (0) }\end{array}$ & P Values \\
\hline ATT1 <- ATT & 0.707 & 0.000 \\
\hline ATT4 <- ATT & 0.696 & 0.000 \\
\hline ATT5 <- ATT & 0.848 & 0.000 \\
\hline ATT6 <- ATT & 0.675 & 0.000 \\
\hline COM2 <- COM & 0.685 & 0.000 \\
\hline COM3 <- COM & 0.727 & 0.000 \\
\hline COM4 <- COM & 0.693 & 0.000 \\
\hline COM7 <- COM & 0.700 & 0.000 \\
\hline COM8 <- COM & 0.743 & 0.000 \\
\hline EOU2 <- EOU & 0.721 & 0.000 \\
\hline EOU3 <- EOU & 0.674 & 0.000 \\
\hline EOU5 <- EOU & 0.698 & 0.000 \\
\hline EOU6 <- EOU & 0.787 & 0.000 \\
\hline PEOU1 <- PEOU & 0.575 & 0.000 \\
\hline PEOU2 <- PEOU & 0.748 & 0.000 \\
\hline PEOU3 <- PEOU & 0.789 & 0.000 \\
\hline PEOU4 <- PEOU & 0.726 & 0.000 \\
\hline $\mathrm{PI} 1<-\mathrm{PI}$ & 0.622 & 0.000 \\
\hline $\mathrm{PI} 2<-\mathrm{PI}$ & 0.896 & 0.000 \\
\hline$P \mid 3<-P I$ & 0.873 & 0.000 \\
\hline
\end{tabular}

Table 1 : Outer loadings

The validity of the model is indicated by conducting the path coefficient. According to Henseler et. al. (2009), the individual path coefficients measure the degree of the causal relationship between constructs. The outcome of the structural path analysis is provided in Figure 2 whereby all the PLS path coefficients is shown. As seen from the diagram above, despite all the path coefficients being above positive and zero, the path COMP to Attitude reported the path coefficient of 0.046 which is close to zero. This indicates the causal relationship between these two variables is not significant. The result of the hypothesis testing is shown below. Path coefficients produced by the bootstrapping procedure. Bootstrapping is any test or metric that relies on random sampling that uses the replacement of observations. In order to estimate the significance of the path coefficients for the hypothesis $\mathrm{H} 1$ to $\mathrm{H} 4$, the bootstrapping procedure in Smart PLS was used. As mentioned earlier, for any path coefficient to be significant, it has to be above zero. The t-statistics must also be preferably above 1. As seen in Table 2, for $\mathrm{H} 1(\beta=0.472, \mathrm{t}=10.787), \mathrm{H} 2(\beta=0.205, \mathrm{t}=4.656)$ and $\mathrm{H} 4(\beta=0.537$, $t=17.036)$ therefore, these hypotheses are all meeting the abovementioned criteria and are all supported. The use of the construct Attitude as a mediator is tested and made possible by the 
procedure recommended Preacher \& Hayes (2008) rather than the Sobel (1982) test. The reason for this is that it does not have strict distributional assumption (Hair et. al., 2014). For this procedure, in order to test for mediation strength, the figures for variance account for (VAF) is employed. According to Hair et. al. (2014), partial mediation is demonstrated when the VAF exceeds the $20 \%$ threshold whilst readings of above $80 \%$ indicates full mediation. No mediation occurs when the VAF figure is less that $20 \%$. For $\mathrm{H} 5 \mathrm{a}$, the $\mathrm{VAF}$ figure is $82.2 \%$ which indicates full mediation. For $\mathrm{H} 5 \mathrm{~b}$ and $\mathrm{H} 5 \mathrm{c}$ the VAF figures are $49.7 \%$ and $31.1 \%$ respectively and this indicates partial mediation. This means that $\mathrm{H} 5 \mathrm{a}, \mathrm{H} 5 \mathrm{~b}$ and $\mathrm{H} 5 \mathrm{c}$ is all accepted.

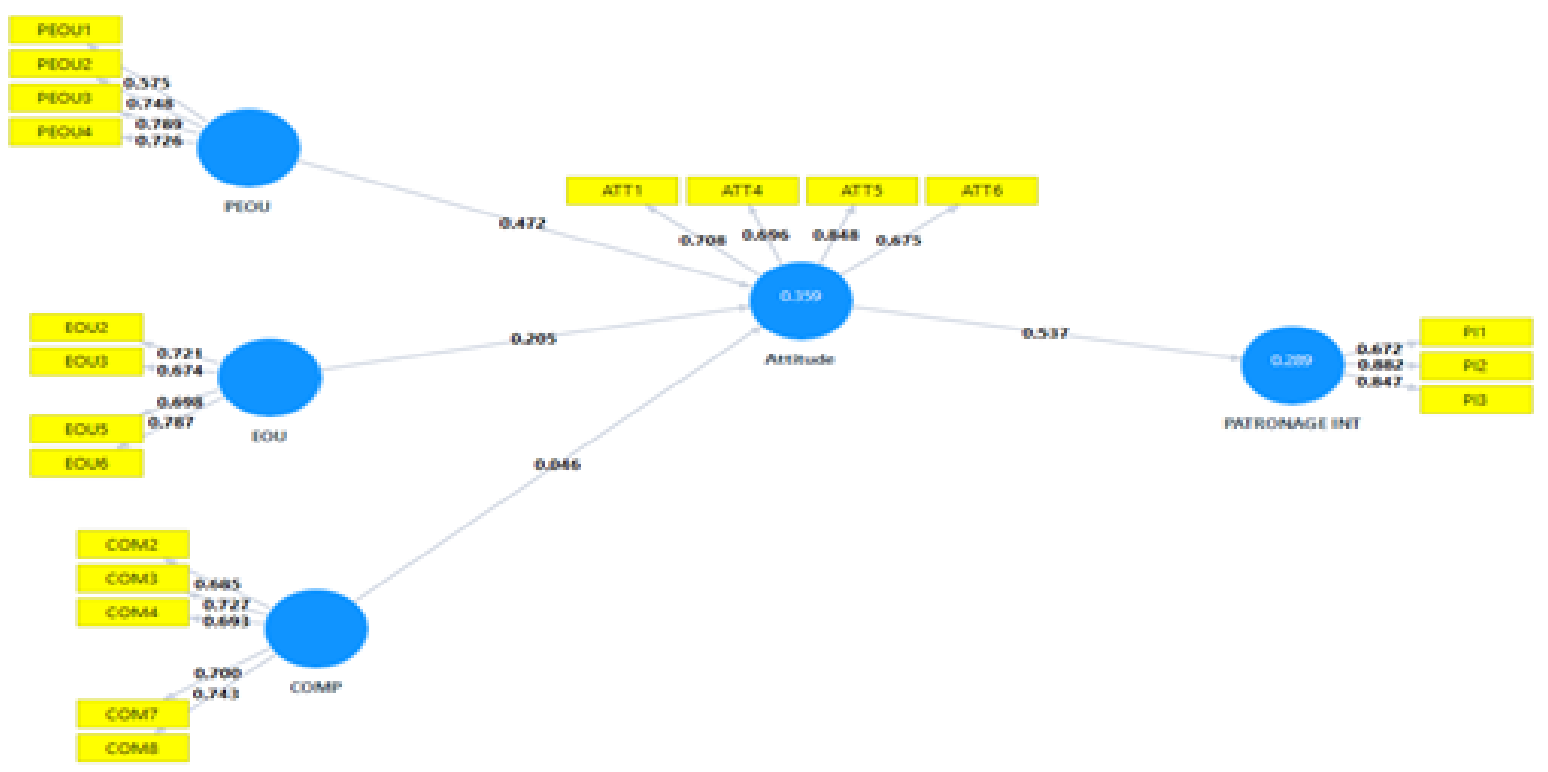

Figure 2 : Outcome of the Structural Path Analysis 
INTERNATIONAL JOURNAL OF ACADEMIC RESEARCH IN BUSINESS AND SOCIAL SCIENCES Vol. 8, No. 11, Nov, 2018, E-ISSN: 2222-6990 @ 2018 HRMARS

\begin{tabular}{|c|c|c|c|c|c|c|c|c|c|c|}
\hline Hyp & Procedure & PATH & $\begin{array}{l}\text { Path } \\
\text { Coeffldents } \beta\end{array}$ & $\begin{array}{l}\text { Indirect } \\
\text { effect }\end{array}$ & 5 td dev & $\begin{array}{l}\text { Total } \\
\text { effacts }\end{array}$ & $\mid \begin{array}{l}\mathrm{T} \\
\text { Statistics }\end{array}$ & vaF & Pvalues & Result \\
\hline $\mathrm{H} 1$ & & PRDU-> A Erituds & 0.472 & \multirow{4}{*}{ NA } & \multirow{4}{*}{ NA } & \multirow{4}{*}{ Nea } & 10.787 & \multirow{4}{*}{ Na } & 0 & Supportsd \\
\hline $\mathrm{Hz}$ & & BOU $\rightarrow A$ Areds & 0.205 & & & & 4.656 & & 0 & Supporsd \\
\hline $\mathrm{H3}$ & & COMP - A AErude & 0.046 & & & & 0.916 & & 0.36 & $\begin{array}{l}\text { Not } \\
\text { auninorest }\end{array}$ \\
\hline $\mathrm{H} 4$ & & $\begin{array}{l}\text { Aetevde-> Patronag } \\
\text { intengon }\end{array}$ & 0.537 & & & & 17.036 & & 0 & Supports \\
\hline \multirow{4}{*}{ H5a } & $\begin{array}{l}\text { Stp I Direct } \\
\text { offect } \\
\text { (without } \\
\text { modiager) }\end{array}$ & $\begin{array}{l}\text { PEDU -s Patronag } \\
\text { intenton }\end{array}$ & 0.309 & \multirow[t]{2}{*}{ NA } & NA & Nea & 6.074 & NA & 0 & \multirow{4}{*}{$\begin{array}{l}\text { Full } \\
\text { medias on } \\
\text { (Supportsd) }\end{array}$} \\
\hline & $\sin \quad z$ & $\begin{array}{l}\text { PEOU-> Patronag } \\
\text { intenteon }\end{array}$ & 0.309 & & \multirow{3}{*}{0.023} & \multirow{3}{*}{0.309} & \multirow{3}{*}{9.011322} & \multirow{3}{*}{$0.82 z$} & \multirow{3}{*}{0} & \\
\hline & Indirect & PEDU-> A=ribuds & 0.472 & \multirow[b]{2}{*}{0.254} & & & & & & \\
\hline & madiasr) & $\begin{array}{l}\text { Aetedude-> Patronag } \\
\text { intentoon }\end{array}$ & 0.537 & & & & & & & \\
\hline \multirow{4}{*}{ H5b } & $\begin{array}{l}\text { Sxp l Direct } \\
\text { offect } \\
\text { (without } \\
\text { modiagr) }\end{array}$ & $\begin{array}{l}\text { gDU -> Patro nage } \\
\text { intentaon }\end{array}$ & 0.221 & \multirow[t]{2}{*}{ NA } & NA & NeA & 4814 & Na & 0 & \multirow{4}{*}{$\begin{array}{l}\text { Partal } \\
\text { mediazon } \\
\text { (Supportad) }\end{array}$} \\
\hline & $\operatorname{sip} \quad z$ & $\begin{array}{l}\text { EDU -> Patro nage } \\
\text { intsengon }\end{array}$ & 0.221 & & \multirow{3}{*}{0.025} & \multirow{3}{*}{0.221} & \multirow{3}{*}{4.396892} & \multirow{3}{*}{0.497} & \multirow{3}{*}{0} & \\
\hline & $\begin{array}{l}\text { Indirat } \\
\text { effect (with th }\end{array}$ & BOU - $>$ A ared de & 0.205 & \multirow[b]{2}{*}{0.11} & & & & & & \\
\hline & madiasr) & $\begin{array}{l}\text { eeteude-> Patro nag } \\
\text { intentoon }\end{array}$ & 0.537 & & & & & & & \\
\hline \multirow{4}{*}{ H5C } & $\begin{array}{l}\text { Stp l Direct } \\
\text { offect } \\
\text { (without } \\
\text { modiagr) }\end{array}$ & $\begin{array}{l}\text { COMP - Patronag } \\
\text { intention }\end{array}$ & 0.077 & \multirow[t]{2}{*}{ NA } & NA & Na & 1568 & Na & 0.117 & \multirow{4}{*}{$\begin{array}{l}\text { Pardal } \\
\text { mediazon } \\
\text { (Supportad) }\end{array}$} \\
\hline & \multirow{3}{*}{$\begin{array}{l}5=p \\
\text { Indiract } \\
\text { offect (with } \\
\text { mediasr) }\end{array}$} & $\begin{array}{l}\text { COMP -s Patronag: } \\
\text { intengon }\end{array}$ & 0.077 & & \multirow[b]{3}{*}{0.027} & \multirow{3}{*}{0.077} & \multirow{3}{*}{0.896245} & \multirow[b]{3}{*}{0.311} & \multirow[b]{3}{*}{0.366} & \\
\hline & & COMP $->$ AErtuds & 0.046 & & & & & & & \\
\hline & & $\begin{array}{l}\text { Leteuds \& Patronags } \\
\text { intention }\end{array}$ & 0.537 & 0.024 & & & & & & \\
\hline
\end{tabular}

Table 2: Hypothesis result

\section{DISCUSSIONS}

This study has provided some interesting insights especially establishing the attitudes of women towards particular shopping centres. The findings have a few implications that should be of primary focus to shopping centre management as well as all relevant parties. Firstly, the respondents for this study viewed shopping as a utilitarian function and thus the intention to patronise a shopping centre highly depends on the utilitarian retail attributes (PEOU and EOU) available in the shopping centre. This means that they the availability of good price promotions, product assortment, convenience, sales personnel and post transaction satisfaction plays a significant role in attracting them to a shopping centre. Most of the respondents did not view that the hedonic retail attributes (COMP) in a shopping centre would actually entice them to patronise it. This indicates that whilst shopping is a leisurely and recreational activity, women were still more willing to derive satisfaction on the utilitarian retail attributes. 


\section{CONCLUSION}

From the theoretical perspective, the decomposition of the attitude constructs into PEOU, EOU and COMP produces a better reading. Previously, the DTPB was originally used in the technology adoption behaviour. Previous attempts to treat the TPB as decompose the have been found in previous studies. From the management perspective, in order to achieve customer satisfaction and ultimately loyalty, focus should be on ensuring that there is value for money products available that are big on variety. This comes from having the right balance of tenant mix that could offer this. Services provided should be top priority as well. As for hedonic retail attributes (COMP), management should not neglect this portion as well. Perhaps further studies on this area in a collectivist nation like Malaysia should be conducted to ascertain the different stimulus that might entice different groups of shoppers. This research shows that attitude towards a shopping centre mediates the strengths between utilitarian retail attributes (PEOU and EOU) as well as hedonic retail attributes (COMP) and patronage intention. Management of shopping centres should understand the needs and wants of shoppers, react to their concerns and keep them satisfied as well. Basically, the higher the utilitarian retail attributes (PEOU and EOU).

\section{Corresponding Author}

Evelyn Toh Bee Hwa

Sunway University Business School, Sunway University, No. 5, Jalan Universiti, Bandar Sunway, 47500, Selangor D. Ehsan, Malaysia

Email: evelyntoh@sunway.edu.my

\section{References}

Ajzen, I. \& Fishbein, M. (1980), Understanding attitudes and predicting social behaviour. Engle Cliffs, NJ. Prentice Hall.

Ahmed, Z. U., Ghingold, M. \& Dahari, Z., (2007), Malaysian Shopping mall behaviour: an exploratory study, Asia Pacific Journal of Marketing and Logistics, 19(4), 331-348.

Babin, B. J., Chebat, J. C. \& Michon, R. (2004), Perceived appropriateness and its effect on quality, affect and behaviour, Journal of Retailing and Consumer Services, 287 - 298.

Baharun, R., Mirghasemi, F., Rahman, N. S. A. \& Awang, Z. (2015), Application of Decomposed Theory of Planned Behaviour on Post Graduate students toward on-line shopping, Jurnal Kemanusiaan, 24(1), 30-42.

Darden, W. R., Erdem, O. \& Darden, D.K. (1983), "A comparison and test of three causal models of patronage intentions", in Darden, W.R. and Lusch, R.F. (Eds), Patronage Behavior and Retail Management, Nort-Holland, New York, NY, pp. 29-43.

Darian, J. C., Wimana, A. R. \& Tucci, L. A. (2005), Retail patronage intentions: the relative importance of perceived prices and salesperson service attributes, Journal of Retailing and Consumer Services, $12,15-23$.

Davis, F.D. (1989), Perceived usefulness, Perceived ease of use, and User Acceptance of Information Technology, MIS Quarterly, 319-340.

De Nisco, A \& Napolitano, M. R. (2006), Entertainment Orientation of Italian Shopping Centres : Antecedent and Performance, Managing Service Quality, 16(2), 145. 
INTERNATIONAL JOURNAL OF ACADEMIC RESEARCH IN BUSINESS AND SOCIAL SCIENCES

Vol. 8, No. 11, Nov, 2018, E-ISSN: 2222-6990 @ 2018 HRMARS

Eagly, A.H. and Chaiken, S. (1993), The Psychology of Attitudes, Harcourt Brace, Orlando, FL.

Fishbein, M. A. \& Ajzen, I. (1975), Beliefs, attitude, intention and behaviour : An introduction to theory and research, Reading MA, Addison-Wesley.

Hair, J. F., Hult, G. T. M., Ringle, C. M. \& Sarstedt, M. (2014), A primer on Partial Least Squares Structural Equation Modeling (PLS-SEM), Sage Publications Inc., UK.

Henseler, J., Ringle, C. M \& Sinkovics, R. R. (2009), The use of Partial Least Squares Path Modeling in International Marketing, Advances in International Marketing, 20, 277-319.

ICSC Report. (2013), www.icsc.org.

Jorgensen, B. S. \& Stedman, R. C. (2001), Sense of place as an attitude : Lakeshore owners attitudes toward their properties, Journal of Environmental Psychology, 21, 233-248.

Kotler, P. (1973), Atmospherics as a marketing tool, Journal of Retailing, 49(4), 48-64.

Lee, M. Y, Atkins, K. G., Kim, Y. K. \& Park, S. H., (2006), Competitive Analyses between Regional Malls and Big-box retailers : A correspondence analysis for segmentation and positioning, Journal of Shopping Centre Research, 13(1), 81-98.

Lutz, R. J., MacKenzie, S. B. \& Belch, G. E. (1983), Attitude toward the ad as a mediator of advertising effectiveness : Determinants and Consequences, Advances in Consumer Research, 10, 532-539.

Morschett, D., Swoboda, B. \& Foscht, T. (2005), Perception of store attributes and overall attitude towards grocery retailers : The role of shopping motives, The International Review of Retail, Distribution and Consumer Research, 15(4), 423-447.

Newman, A. \& Cullen, P. (2002), Retailing: Environment and Operations, Thomson Learning, London.

Pan, Y. \& Zinkhan, G. M., (2005), Determinants of retail patronage : A meta-analytical perspective, Journal of Retailing, 82(3), 229-243.

Preacher, K. J. \& Hayes, A. F. (2008), Asymptotic and resampling strategies for assessing and comparing indirect effects in multiple mediator models, Behavior Research Methods, 40 (3), 879891.

Rogers, E. M. (2003) Diffusion of Innovations, $5^{\text {th }}$ Edn, Free Press, New York, US.

Said, I., Gambo, N. \& Ismail, R. (2016), An evaluation into the architectural factors attracting customers to Malaysian shopping malls, Journal of Business and Retail Management Research, 11(1), 138-153.

Schiffman, L. \& Kanuk, L. (2010), Consumer Behaviour, 10 ${ }^{\text {th }}$ edn, Prentice Hall. UK.

Sharifuddin, J., Ramalingam, L., Zainalabidin, M. \& Rezai, G. (2014), Factors affecting intention to purchase edible bird's nest products : The case of Malaysian Consumers, Journal of Food Products Marketing, 20, 75-84.

Shimp, T. A. (1981), Attitude toward the AD as a Mediator of Consumer Brand Choice, Journal of Advertising, 10(2), 9-48.

Sirgy, M. J. (1982), Self-concept in consumer behaviour: A critical review, Journal of Consumer Research, 9(3), 287-300.

Sirgy, M. J. (1985), Using Self-Congruity and Ideal Congruity to predict purchase motivation, Journal of Business Research, 13, 195-206.

Sirgy, M. J., Grewal, D. \& Mangleburg, T., (2000), Retail environment, Self-Congruity and Retail Patronage : An integrative model and a research agenda, Journal of Business Research, 49, 127138. 
Sirgy, M. J. \& Samli, A. S., (1985), A Path Analytic model of store loyalty involving self-concept, store image, geographic loyalty, and socioeconomic status, Journal of the Academy of Marketing Science, 13(3), 265-291.

Sobel, M. E. (1982). Asymptotic intervals for indirect effects in structural equations models. In S. Leinhart (Ed.), Sociological methodology 1982 (pp.290-312).

Spears, N. \& Singh, S. N. (2004), Measuring Attitude toward the Brand and Purchase Intentions, Journal of Current Issues \& Research in Advertising, 26(2), 53-66.

Tai, S. H. C. \& Fung, A.M.C. (1997), “Application of an environment psychology model to in-store buying behavior", The International Review of Retail, Distribution and Consumer Behavior, 7(4), 311-337.

Taylor, S. \& Todd, P. A. (1995). Understanding Information Technology Usage : A Test of Competing models, Information System Research, 144-176.

Teller, C. \& Reutterer, T. (2008), The evolving concept of retail attractiveness: what makes retail agglomerations attractive when customers shop at them? Journal of Retailing and Consumer Services, 15(3), 127-143.

Toh, E. B. H. \& Perumal, S. (2017], Determinants of Retail Patronage - A systematic literature review perspective, International Post graduate Business Journal, UUM Press, Dec 2017 (in print)

Turley, L. W. \& Milliman, R. E. (2000), "Atmospheric effects on shopping behavior: a review of the experimental evidence", Journal of Business Research, 49(2), 193-211.

Walters, D. \& Laffy, D. (1996), Managing retail productivity and profitability, Basingstoke : Macmillan Business.

Zhou, L. \& Wong, A. (2003), "Consumer impulse buying and in-store in Chinese supermarkets", Journal of International Consumer Marketing, 16(2), 37-53. 